\title{
Perilaku Konsumsi Mie Instan Pada Remaja di Bangka Belitung
}

\author{
${ }^{1}$ Wiwin Efrizal* \\ ${ }^{1}$ Dinas Kesehatan Provinsi Kepulauan Bangka Belitung \\ Email: wiwinefrizal@gmail.com
}

\section{Kata kunci : \\ Perilaku, Makan, \\ Remaja. \\ Keywords : \\ Adolescent, Eating, \\ Behavior.}

Info Artikel :

Tanggal dikirim :

14 September 2020

Tanggal direvisi :

21 September 2020

Tanggal diterima :

22 September 2020

\section{DOI Artikel :}

10.33862/citradelima. $\mathrm{v} 4 \mathrm{i} 2.119$

Halaman: $94-100$

\section{Abstrak}

Mie instan sebagai makanan yang bersifat praktis, mudah dihidangkan, enak, banyak pilihan rasa dan harga yang murah sangat digemari berbagai kalangan, termasuk remaja. Meskipun demikian, konsumsi mie instan yang berlebihan dapat menimbulkan bahaya bagi kesehatan. Penulis ingin mengetahui perilaku remaja di Bangka Belitung dalam mengkonsumsi mie instan. Penelitian kuantitatif menggunakan metode angket pada akhir agustus 2020 kepada 45 orang responden secara acak dan data yang diperoleh dianalisa secara deskriktif dan metode grafik. Pada penelitian ini ditemukan bahwa perilaku konsumsi mie instan telah dilakukan $84,4 \%$ responden saat usia Sekolah Dasar dengan prosentase $71,1 \%$ mengkonsuminya 1-3 bungkus per minggu. Perilaku lain saat pengolahan/penyajiannya sebanyak $51,1 \%$ responden berpendapat senang menambahkan bumbu/bahan makanan lain untuk meningkatkan rasa/selera dan asupan gizi.

\section{The Behavior of Consuming Instant Noodles in Adolescents in Bangka Belitung}

Abstract
Instant noodles as a practical food, easy to serve, delicious, many choices of flavors and
cheap prices are very popular with various groups, including teenagers. Even so, excessive
consumption of instant noodles can cause health hazards. The author wants to know the
behavior of adolescents in Bangka Belitung in consuming instant noodles. Quantitative
research used a questionnaire method at the end of August 2020 to 45 respondents
randomly and the data obtained were analyzed descriptively and graphically. In this study,
it was found that the behavior of consuming instant noodles was carried out by $84.4 \%$ of
respondents at elementary school age with a percentage of $71.1 \%$ consuming 1-3 packs per
week. Other behavior when processing / serving it as much as $51.1 \%$ of respondents think
they like adding spices / other food ingredients to increase taste / taste and nutritional
intake.




\section{PENDAHULUAN}

Mie instan merupakan produk mie berbentuk blok yang siap dimasak dan biasanya dalam kondisi kering disertai bumbu dan/atau minyak bumbu yang dikemas dalam kemasan terpisah. Blok mie kering sebelum dikonsumsi, biasanya direndam dalam air mendidih dalam waktu tertentu dan dikonsumsi setelah ditambahkan bumbu yang telah disediakan. Mie instan awalnya diperkenalkan oleh Momofuku Ando dari Nissin Food Jepang pada tahun 1958, dan selanjutnya memperkenalkan produk mie instan yang dikemas dalam gelas polisterena tahun 1971 (Harsanto, 2015). Mie instan yang bersifat praktis, mudah dihidangkan, enak, banyak pilihan rasa dan harga yang terjangkau menjadi makanan paling digemari semua kalangan. Meskipun mi instan memiliki aneka rasa yang beragam, namun nilai kandungan gizi yang terkandung dalam setiap kemasannya mempunyai kandungan natrium, gula dan protein yang hampir sama (Ete, 2014).

Mie instan dikonsumsi dengan alasan sebagian besar konsumen tidak mempunyai waktu yang cukup untuk dapat mengkonsumsi makanan lengkap, terutama untuk memasak dan menyajikannya. Kondisi yang ingin serba cepat dan semakin meningkatkan aktivitas sehari-hari mendorong konsumen untuk mengkonsumsi mie instan. Namun, konsumsi mie instan yang terlalu sering dapat memberikan risiko dan bahaya bagi Kesehatan, karena mengandung bahan pengawet, dan rendahnya kandungan zat gizi yang ada (Harsanto, 2015). Pengaruh dari teman sebaya merupakan faktor paling berpengaruh dalam konsumsi mie instan dan tersedianya mie instan yang banyak serta mudah diperoleh mendorong keinginan untuk mengkonsumsi mie instan (Arza, 2017). Untuk itu, Penulis ingin mengetahui perilaku remaja di Bangka Belitung dalam mengkonsumsi mie instan.

\section{METODE}

Penelitian ini adalah penelitian kuantitatif dan pengumpulan data menggunakan metode angket (kuesioner). Sampel penelitian ini adalah remaja di Provinsi Kepulauan Bangka Belitung yang dikirimkan tautan angket secara acak sebanyak 45 orang responden. Pengumpulan data dilakukan selama satu minggu pada akhir agustus 2020. Analisa data menggunakan metode statistic deskriptif dan metode grafik.

\section{HASIL DAN PEMBAHASAN}

\section{Informasi Responden}

Sebagian besar responden dalam penelitian ini adalah remaja berusia di bawah 20 tahun dengan latar belakang pendidikan paling banyak Sekolah Menengah Atas (SMA) sederajat sebagaimana ditampilkan dalam gambar 1. Remaja yang bersekolah di Sekolah Menengah Atas (SMA) pada umumnya adalah remaja yang mempunyai karakteristik fase peralihan dengan adanya perubahan fisik dan psikis (Diananda, 2019). Secara psikologis, seorang remaja ditandai dengan sikap dan perasaan, keinginan dan emosi yang labil atau tidak menentu dan pada masa ini, pengaruh teman sebaya sangat besar (Bariyyah, 2016). Teman sebaya merupakan salah satu faktor eksternal yang paling berpengaruh dalam konsumsi mie instan pada remaja (Arza, 2017).

Gambar 1

Proporsi Responden menurut Kelompok Umur dan Tingkat Pendidikan Terakhir a. Proporsi Responden menurut Kelompok Umur

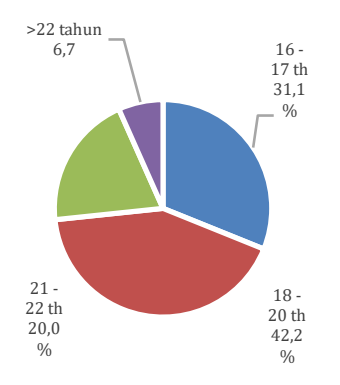

b. Proporsi Responden menurut Tingkat Pendidikan Terakhir

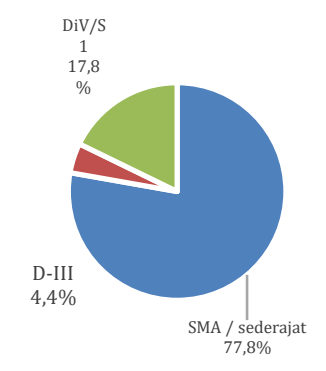

Gambar 1.a. menjelaskan proporsi responden menurut kelompok umur yang sebagian besar terdiri dari remaja berusia 18 - 20 tahun dan gambar 1.b menjelaskan proporsi responden menurut tingkat pendidikan terakhir yang sebagian besar lulusan SMA/sederajat.

\section{Frekuensi Konsumsi Mie Instan}

Sebagian remaja telah mengkonsumsi mie instan sejak usia Sekolah Dasar (SD) sebagaimana ditunjukkan pada gambar 2. Konsumsi mie instan pada usia Sekolah Dasar sering disebabkan oleh gencarnya pengaruh iklan, ajakan teman, dan adanya pemberian mie instan oleh orang tua/keluarga atau teman pada saat pertama tersebut. Beberapa faktor yang mempengaruhi seseorang mengkonsumsi mie instan adalah tingkat pengetahuan yang masih rendah pada saat Sekolah Dasar, adanya ajakan/pengaruh dari iklan/media massa http://jurnalilmiah.stikescitradelima.ac.id/index.php/JI Vol.4, No.2, Januari 2021 
dan/atau teman sebaya serta lingkungan sosial, termasuk dukungan keluarga yang mengizinkan konsumsi mie instan, serta ketersediaan mie instan, terutama di tingkat rumah tangga (Arza, 2017). Mie instan yang terasa enak, praktis, dan murah menjadi alasan responden untuk mengkonsumsi mie instan (Ratnasari, 2012).

\section{Gambar 2}

Usia Remaja saat Mengkonsumsi Mie Instan Pertama Kali

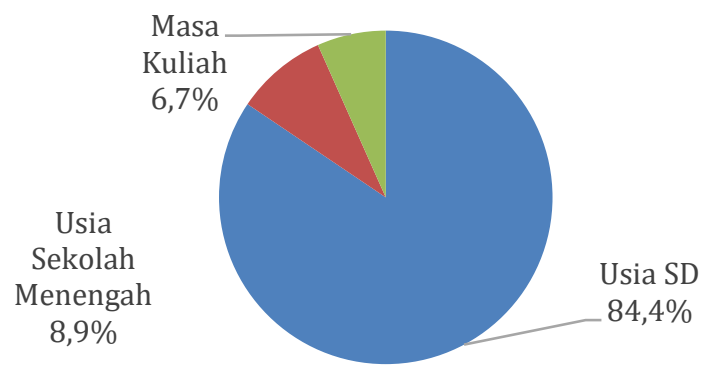

Gambar 2 menjelaskan proporsi kelompok usia sekolah remaja saat pertama kali mengkonsumsi mie instan

Sebagian besar responden dalam satu minggu terakhir pernah mengkonsumsi mie instan sebagaimana ditampilkan pada gambar 3. Pada umumnya, remaja mengkonsumsi sebanyak $1-3$ bungkus mie instan dalam satu minggu. Frekuensi konsumsi mie instan seiring dengan aspek mie instan yang mudah diolah, cepat disajikan, murah dan praktis, sehingga tidak mengganggu aktivitas. Konsumsi mie instan, selain dengan alasan fisiologis yang disebabkan rasa lapar, perasaan dan suasana hati, namun juga adanya alasan kebutuhan social dalam bentuk konformitas antara teman sebaya dan gengsi (Risyanu, 2019).

Gambar 3

Konsumsi mie instan pada remaja dalam waktu seminggu terakhir

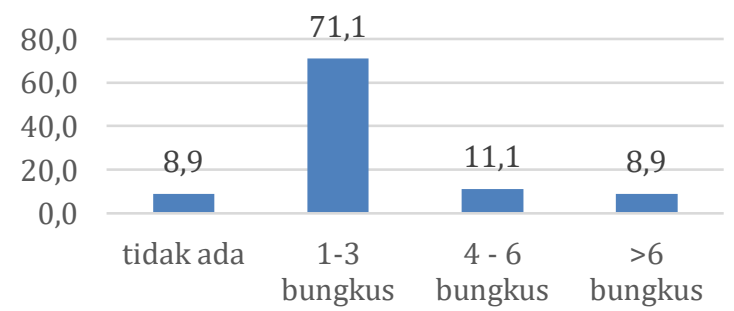

Gambar 3 menjelaskan jumlah porsi mie instan yang dikonsumsi oleh remaja dalam waktu seminggu terakhir

\section{Pengolahan dan Penyajian Mie Instan}

Sebagian besar remaja menambahkan bahan makanan lain dalam pengolahan dan penyajian mie instan sebagaimana disajikan pada gambar 4. Bahan makanan yang ditambahkan adalah telur, sayuran, nasi, kerupuk, sosis, daging, ayam, bakso, keju, dan ikan. Penambahan bahan makanan tersebut dilakukan sesuai dengan selera masing-masing dalam jumlah yang tidak dapat dipastikan, karena sangat tergantung pada selera dan ketersediaan bahan makanan yang ditambahkan tersebut pada saat pengolahan dan penyajian.

\section{Gambar 4 \\ Penambahkan Bahan Makanan Lain saat Mengolah Mie Instan}

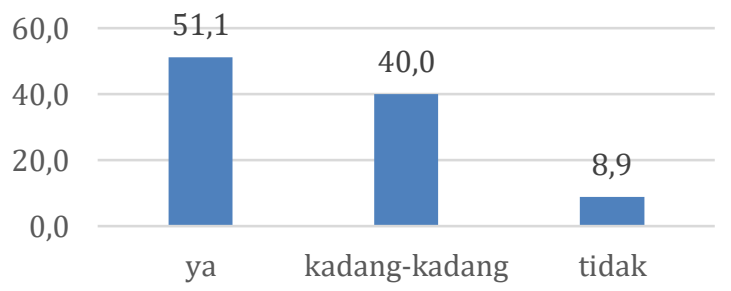

Gambar 4 menjelaskan seringnya penambahan bahan makanan lain oleh remaja pada saat mengolah/ menyajikan mie instan

Penambahan bahan makanan lain akan dapat memberikan kebutuhan gizi yang seimbang bagi tubuh, karena mie instan dengan bahan utama tepung terigu lebih banyak mengandung karbohidrat, sehingga diperlukan tambahan sumber protein, dan lemak serta sayuran (Ratnasari, 2012). Kurangnya pemenuhan kebutuhan gizi dari mie instan ini merupakan salah satu alasan responden untuk melakukan penambahan bahan makan lain dalam pengolahan dan penyajian mie instan. Penambahan bahan makanan lain dalam pengolahan mie instan memberikan kondisi yang menguntungkan, karena meningkatkan keanekaragaman bahan makanan, dan nilai gizi mie instan. Namun, frekuensi konsumsi mie instan tidak memberikan pengaruh terhadap tingkat kecukupan gizi pada remaja (Kurnianingsi, 2017). Sebanyak 12 orang atau $26,7 \%$ responden menyatakan konsumsi mie instan tidak memenuhi kebutuhan gizi dan sebanyak 29 orang atau $64,4 \%$ meragukan pemenuhan kebutuhan gizi dari mie instan. 
Gambar 5

Penambahan Bumbu Lain dan Bahaya Mie Instan menurut Remaja

a. Penambahan Bumbu

b. Bahaya Mie Instan Lain
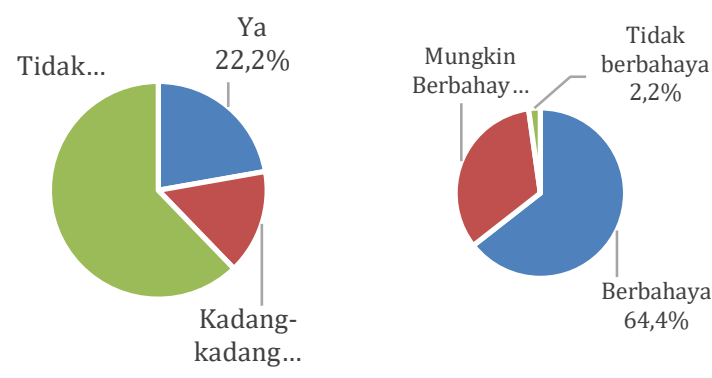

Gambar 5.a. menjelaskan penambahan bumbu lain selain bumbu yang disediakan dalam kemasan mie instan pada saat pengolahan/penyajian dan gambar 5.b. menjelaskan proporsi remaja yang berpendapat tentang bahaya mie instan bagi kesehatan

Dalam mengkonsumsi mie instan, sebagian besar remaja tidak menambahkan bumbu selain bumbu yang telah disediakan dalam kemasan sebagaimana disajikan pada gambar 5.a. Bumbu yang ada dalam kemasan mie instan umumnya dikemas tersendiri dan mengandung Monosodium Glutamat (MSG) atau vetsin yang terdiri dari garam organic antara lain natrium (sodium) dan glutamate. Sebagian remaja menambahkan bumbu lain dalam pengolahan mie instan dengan tujuan menambah cita rasa. Bumbubumbu yang ditambahkan antara lain cabai, bawang, jeruk nipis, sambal, kecap, garam, dan bumbu penyedap. Penambahan bumbu-bumbu tersebut dilakukan dalam jumlah yang disesuaikan dengan selera masing-masing.

Pada gambar 5.b diketahui sebagian besar remaja berpendapat bahwa mie instan berbahaya bagi Kesehatan. Konsumsi mie instan berbahaya karena dapat menyebabkan peningkatan berat badan atau obesitas, memperberat sistem pencernaan, dapat menyebabkan usus buntu, penyakit maag, menyebabkan kanker, dan tekanan darah tinggi. Adanya pengawet dalam mie instan dianggap remaja sebagai sumber bahaya konsumsi mie instan bagi kesehatan. Berbagai bahan tambahan guna memperkaya rasa dan penampilan ditambahkan pada mie instan. Mie instan mengandung garam natrium yang cukup tinggi dan sumber natrium utamanya adalah sodium carbonat dan monosodium glutamate (MSG) (Sulastri, 2014).
Tabel 1.

Penambahan Bumbu/Bahan Makanan Lain menurut Tingkat Pendidikan

\begin{tabular}{|l|c|c|c|c|c|c|c|c|}
\hline & \multicolumn{6}{|c|}{ Penambahan bumbu/bahan makanan lain } \\
\cline { 2 - 10 } & \multicolumn{2}{|c|}{ Iya } & \multicolumn{2}{c|}{$\begin{array}{c}\text { Kadang- } \\
\text { kadang }\end{array}$} & \multicolumn{2}{c|}{ Tidak } & \multicolumn{2}{c|}{ Jumlah } \\
\hline $\begin{array}{l}\text { Tingkat } \\
\text { Pendidikan }\end{array}$ & $\mathrm{n}$ & $\%$ & $\mathrm{n}$ & $\%$ & $\mathrm{n}$ & $\%$ & $\mathrm{n}$ & $\%$ \\
\hline $\begin{array}{l}\text { SMA/ } \\
\text { sederajat }\end{array}$ & 18 & 40,0 & 14 & 31,1 & 3 & 6,7 & 35 & 77,8 \\
\hline Diploma III & 1 & 2,2 & 1 & 2,2 & 0 & 0,0 & 2 & 4,4 \\
\hline $\begin{array}{l}\text { Diploma } \\
\text { IV/Sarjana }\end{array}$ & 4 & 8,9 & 3 & 6,7 & 1 & 2,2 & 8 & 17,8 \\
\hline Jumlah & 23 & 51,1 & 18 & 40,0 & 4 & 8,9 & 45 & 100 \\
\hline
\end{tabular}

Tabel 1 tabulasi silang variabel tingkat pendidikan remaja dibandingkan variabel penambahan bumbu/bahan makanan lain pada saat mengolah/menyajikan mie instan.

Pada tabel 1 terlihat sebagian besar responden lulusan SMA menambahkan bumbu/baham makanan lain dalam pengolahan/penyajian mie instan, dan hanya sebagian kecil yang melakukanya pada responden lulusan Diploma III. Tingkat pendidikan seseorang mempengaruhi tingkat pengetahuan, namun pengetahuan yang baik tentang gizi seimbang tidak mendorong seseorang untuk mengkonsumsi mie instan. Tingginya minat untuk mengkonsumsi mie instan disebabkan oleh kebiasaan seseorang, tersedianya uang untuk membeli mie instan dan kebutuhan makan yang praktis. (Arza, 2017)(Julya, 2016)

\section{Ungkapan Perasaan Saat Mengkonsumsi Mie Instan}

Gambar 6

Rasa Mie Instan menurut Remaja

a. Rasa Mie Instan pada b. Rasa Mie Instan pada

Saat Konsumsi

Pertama

Saat Konsumsi

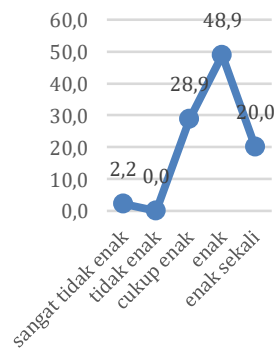

Terakhir

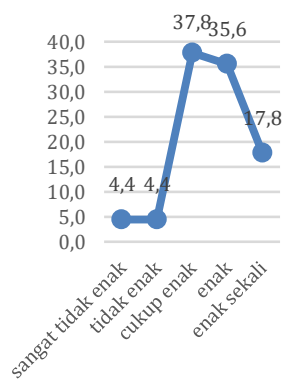

Gambar 6.a. menjelaskan pendapat remaja terkait rasa mie instan pada saat mengkonsumsinya pertama kali dan gambar 6.b. pendapat remaja terkait rasa mie instan pada saaat terakhir mengkonsumsi mie instan

MSG memberikan cita rasa pada makanan yang dikenal dengan "umami", selain empat rasa dasar yang ada, yaitu rasa manis, asam, asin, dan pahit (Fallis,

http://jurnalilmiah.stikescitradelima.ac.id/index.php/JI

Vol.4, No.2, Januari 2021 
2013). Rasa enak dirasakan oleh sebagian besar remaja pada saat pertama kali mengkonsumsi mie instan dan pada konsumsi terakhir mie instan sebagaimana disajikan pada gambar 4. Berbagai varian rasa yang dikembangkan menyebabkan mie instan memberikan lebih banyak pilihan pada konsumen. Penambahan bahan penambah rasa atau flavor selalu dilakukan dalam pembuatan mie instan, sehingga memberikan rasa pada mie instan, seperti rasa soto ayam, ayam bawang, baso, barbeque, rendang, kari ayam dan lainlain.(Harsanto, 2015) Rasa enak yang dirasakan konsumen dalam mengkonsumsi mie instan dapat dipengaruhi oleh sensitivitas lidah sebagai indera pengecap yang dapat berubah disebabkan factor usia, suhu makanan, penyakit, merokok dan menginang (adat kapur sirih).(Tunggala, 2016)

\section{Kecukupan Gizi Dari Mie Instan}

Mie instan mengandung natrium sekitar $600-$ $1.100 \mathrm{mg}$ per porsi (45 - 65\% AKG) dan pengatur keasaman, penstabil (fosfat dan nabati), antioksidan dan pewarna sintetik, sedangkan pada bumbu yang tersedia dalam kemasan mie instan mengandung garam, gula, penguat rasa, perisa sintetik, antioksidan, bawang dan lada bubuk, daun bawang dan vitamin. Asupan natrium yang tinggi akan menyebabkan penumpukkan cairan dalam tubuh yagn disebabkan oleh terjadinya penarikan cairan dari luar sel, sehingga berakibat pada peningkatan volume dan tekanan darah.(Arza, 2017)(Atun, 2016)(Hendriyani, 2016) Meskipun demikian, kadar natrium dapat dipengaruhi oleh beberapa factor antara lain aktifitas yang berlebihan yang menyebabkan konsumsi air akan meningkat, sehingga kadar natrium dalam cairan ekstraseluler akan menurun.(Polii, 2016)

Salah satu penguat rasa yang digunakan adalah monosodium glutamate (MSG). MSG tergolong food additive atau bahan tambahan pangan (BTP) yang diperoleh dari proses hidrolisa protein yang menghasilkan purifikasi glutamate atau gabungan dari beberapa asam asmino dengan sejumlah peptide. MSG berfungsi sebagai penguat dan penyedap rasa jika digunakan sebagai bahan tambahan pangan, terutama pada pangan yang mengandung protein. Sebagian besar senyawa MSG terdiri dari $78 \%$ glutamate, dan sebagian kecil terdiri dari $12 \%$ natrium dan $10 \%$ air. Bila dilarutkan dalam air ataupun saliva, MSG akan berdisosiasi menjadi garam bebas dan bentuk anion dari asam glutamate. Glutamat dapat diproduksi oleh tubuh manusia dan berkaitan dengan asam amino lain membentuk struktur protein yang berperan sebagai neurotransmitter. (Fallis, 2013) Asam glutamate juga berfungsi dalam proses energi, sintesis urea, dan sintesis glutation.(Risyanu, 2019)

Satu porsi mie rebus mengandung 2.250 $2.780 \mathrm{mg}$ dan satu porsi mie goreng mengandung 2.900 - $3.400 \mathrm{mg}$ MSG. Pada remaja dengan berat $45 \mathrm{~kg}$, maka konsumsi MSG tidak boleh melebihi $5.400 \mathrm{mg}$ atau paling banyak 2 porsi mie instan sehari. Konsumsi yang aman tiap hari per orang tidak boleh melebihi ambang batas aman yang telah ditetapkan, yaitu 120 $\mathrm{mg} / \mathrm{kg}$ BB/hari.(Sulastri, 2014) Namun, Badan Pengawas Obat dan Makanan Amerika Serikat menyatakan batas aman penggunaan MSG adalah 2.000 mg/hari.(Risyanu, 2019) Namun, penggunaan MSG sebagai penyedap makanan dibatasi hingga 6 $\mathrm{mg} / \mathrm{kg}$ berat badan. Menurut Federation of American Societies for Experimental Biology (FASEB) menyatakan batas aman konsumsi MSG adalah sebesar 0,5 gr-2,5 gr per hari. (Ratnasari, 2012)(Septadina, 2014)

Konsumsi mie instan secara berlebihan dapat menyebabkan penumpukan zat-zat kimia berbahaya dalam tubuh dan berakibat pada kerusakan sel-sel jaringan otak. Kondisi ini akan menimbulkan efek penurunan transmisi sinyal pada otak yang memicu terjadinya penyakit-penyakit, seperti stroke dan kelumpuhan. (Risyanu, 2019) Penggunaan dengan dosis 2-7 $\mathrm{mg} / \mathrm{kgBB}$ pada beberapa penelitian tidak menunjukkan adanya reaksi alergi, intoleransi dan gangguan lain, namun beberapa penelitian lain menemukan adanya kelainan pada organ tubuh, termasuk system reproduksi yang dapat menyebabkan infertilitas, dan timbulnya gejala Chinese Restaurant Syndrome (CRS) seperti rasa panas di dada, bagian belakang leher dan lengan bawah, sakit kepala, mual, jantung berdebar-debar, sesak napas, dan sering mengantuk (Sulastri, 2014 ; Septadina, 2014).

Upaya untuk mengatasi bahaya mie instan menurut responden adalah membuat mie sendiri, mengurangi bumbu yang ada pada mie instan, mengganti air rebusan mie, mengurangi konsumsi mie instan, dan mengkonsumsi mie instan diiringi dengan olahraga rutin. Pola makan yang sehat merupakan salah satu bentuk upaya mengatasi bahaya konsumsi mie instan. Pola makan dengan memperhatikan gizi seimbang akan dapat memenuhi kebutuhan gizi dan memberikan rasa kenyang yang lebih lama, sehingga konsumsi yang berlebihan akan berkurang (Kencana, 2019). Selain itu, adanya pictorial warning label atau label peringatan berupa gambar penyakit yang disebabkan konsumsi berlebihan mie instan akan dapat mengurangi intensitas pembelian mie instan (Sumi, 2016).

http://jurnalilmiah.stikescitradelima.ac.id/index.php/JI Vol.4, No.2, Januari 2021 


\section{SIMPULAN}

Konsumsi mie instan telah dilakukan oleh remaja sejak usia Sekolah Dasar dan dalam pengolahan/penyajiannya telah ditambahkan bahan makanan lain. Frekuensi konsumsi mie instan oleh remaja dilakukan paling sedikit 1-3 bungkus dalam seminggu. Sebagian besar remaja melakukan penambahan bumbu dan bahan makanan lain pada saat mengolah/menyajikan mie instan agar lebih menambah rasa/selera dan asupan gizi. Penambahan bahan bumbu dan bahan makanan tidak dipengaruhi oleh tingginya tingkat pendidikan remaja. Meskipun sebagian besar remaja mengetahui bahaya konsumsi mie instan yang berlebihan, namun tetap dikonsumsi dengan melakukan upaya mengatasi bahaya dengan cara pengurangan bumbu, penggantian air rebusan mie, dan pengurangan jumlah mie yang dikonsumsi.

\section{DAFTAR PUSTAKA}

Arza, A. E. I., Yulastri, A., \& Fridayati, L. (2018). Faktor-Faktor Yang Mempengaruhi Konsumsi Mie Instan Pada Mahasiswa. E-Journal Home Economic and Tourism, 14(1).

Atun, L., Siswati, T., \& Kurdanti, W. (2014). Asupan sumber natrium, rasio kalium natrium, aktivitas fisik, dan tekanan darah pasien hipertensi. Indonesian Journal of Micronutrition, 6(1), 150177.

Diananda, A. (2019). Psikologi remaja dan permasalahannya. ISTIGHNA: Jurnal Pendidikan dan Pemikiran Islam, 1(1), 116133.

Ete, A. A., Suciptawati, N. L. P., \& Eka, D. P. (2014). Pengelompokan Berbagai Merk Mi Instan Berdasarkan Kemiripan Kandungan Gizi dengan Menggunakan Analisis Biplot. EJournal Matematika, 3(2), 53-63.

Fallis A. Monosodium Glutamat (MSG) Dan Efek Neurotoksisitasnya Pada Sistem Saraf Pusat. J Chem Inf Model. 2013

Fitriani, A. (2018). Faktor-Faktor Yang Mempengaruhi Pola Makan Mi Instan Di Kalangan Mahasiswa Di Yogyakarta Factors Influencing Instant Noodle Consumption Patterns Among Students In Yogyakarta. Medika Respati: Jurnal Ilmiah Kesehatan, 13, 59-70.

Harsanto, P. W. (2009). Gaya Hidup Modern Dan Iklan (Budaya Makan Mi Instan sebagai Identitas). Imaji: Jurnal Seni dan Pendidikan Seni, 7(1).
Hendriyani, H., Sulistyowati, E., \& Noviardhi, A. (2016). Konsumsi makanan tinggi natrium, kesukaan rasa asin, berat badan, dan tekanan darah pada anak sekolah. Jurnal Gizi Klinik Indonesia, 12(3), 89-98.

Hidayati, K. B., \& Farid, M. (2016). Konsep Diri, Adversity Quotient dan Penyesuaian Diri pada Remaja. Persona: Jurnal Psikologi Indonesia, 5(02).

Kencana, D. Pengaruh Mie Instan Bagi Kesehatan Anak Kos Di Jalan Garuda Induk, Kec. Padang Utara, Kota Padang.

Kurnianingsih, S. (2007). Hubungan Konsumsi Mie Instan Dengan Tingkat Kecukupan Gizi Dan Status Gizi Pada Remaja: Studi Kasus di SMA Negeri 2 Nganjuk (Doctoral dissertation, Universitas Airlangga).

Lestari, S., Permatasari, S. D., \& Dara, Y. P. (2017). Bentuk Warning Label (Pictorial, Information and QuestionWarning Label) untuk Menurunkan Intensi Mengkonsumsi Mie Instan pada Mahasiswa di Kota Malang. Jurnal Psikologi Integratif, 4(2), 148-160.

Polii, R., Engka, J. N., \& Sapulete, I. M. (2016). Hubungan kadar natrium dengan tekanan darah pada remaja di Kecamatan Bolangitang Barat Kabupaten Bolaang Mongondow Utara. eBiomedik, 4(2).

Ratnasari, D. K., \& Wirawanni, Y. (2012). Gambaran Kebiasaan Konsumsi Mie Instan Pada Anak Usia 7-12 Tahun Studi Di Sekolah Dasar Kanisius Tlogosari Kulon Semarang (Doctoral dissertation, Diponegoro University).

Risyanu, F. N., Adiyasa, I., \& Laraeni, Y. (2019). Preferensi Dan Pola Konsumsi Mie Instan Pada Mahasiswa Jurusan Gizi Dan Analis Kesehatan Poltekkes Kemenkes Mataram Mataram Yang Tinggal Di Kost Dan Tidak Kost. Jurnal Gizi Prima (Prime Nutrition Journal), 1(1), 1-8.

Septadina, I. S. (2014). Pengaruh monosodium glutamat terhadap sistem reproduksi. In Seminar Bagian Anatomi. Fakultas Kedokteran Universitas Sriwijaya.

Sulastri, S. (2017). Analisis Kadar Monosodium Glutamat (MSG) pada Bumbu Mie Instan yang Diperjualbelikan di Koperasi Wisata Universitas Indonesia Timur. Jurnal Media Laboran, 7(1), 5-9.

Tunggala, S., Dewi, N., \& Asnawati, A. (2016). Perbandingan Sensitivitas Lidah Terhadap Rasa Manis Dan Pahit Pada Orang Menginang Dan

http://jurnalilmiah.stikescitradelima.ac.id/index.php/JI Vol.4, No.2, Januari 2021 
Tidak Menginang Di Kecamatan Lokpaikat

Kabupaten Tapin. Dentino, 1(2), 62-65. 